\title{
Economic analysis and food security contribution of supplemental irrigation and farm ponds: evidence from northern Burkina Faso
}

\author{
Beteo Zongo ${ }^{1,2^{*}} \mathbb{D}$, Bruno Barbier $^{3}$, Abdoulaye Diarra $^{4}$, Malicki Zorom ${ }^{5}$, Calvin Atewamba ${ }^{6}$, Omer S. Combary ${ }^{7}$,
} Souleymane Ouédraogo ${ }^{8}$, Patrice Toé ${ }^{9}$, Yacouba Hamma ${ }^{5}$ and Thomas Dogot ${ }^{2}$

\begin{abstract}
Background: Dry spells are serious obstacles to rainfed agriculture in Sahelian countries. Various water harvesting techniques are used by farmers to reduce the impact of climate variability, but are not sufficient in the case of a prolonged drought lasting 2-3 weeks. The farmers believe supplemental irrigation is a good way to adapt rainfed agriculture to dry spells. In this study, we evaluated the food contribution and profitability of supplemental irrigation of rainfed crops comparing various farm ponds that collect runoff water from the surrounding landscape.

Methods: We analyzed the contribution of supplemental irrigation to food security and compared the profitability of different types of ponds constructed by farmers in northern Burkina Faso. Human cereal requirement was used as indicators to analyze the contribution of supplemental irrigation to food security. The criteria for analyzing the profitability of the selected ponds were gross margin (GM), net present value (NPV), internal rate of return (IRR) and payback period (PBP).

Results: Our results show that the additional yield of corn obtained with supplemental irrigation makes it possible to meet the monthly cereal needs of at least 17 people and generates an additional GM of FCFA 178,483 (US\$ 309.26) compared to no irrigation. The estimate of the NPV, from IRR and PBP showed that the profitability of supplemental irrigation in 15 agricultural seasons varies between the type of ponds constructed.

Conclusions: Given the up-front cost and the farmers' lack of resources, the ponds require a subsidy or a credit policy to facilitate the adoption of supplemental irrigation in Sahelian countries. However, the irrigation strategies to optimize agricultural income remain a field of research to be explored.
\end{abstract}

Keywords: Cereal need, Dry spells, Profitability, Rainfed agriculture, Runoff water

\section{Background}

In the Sahel countries, the agricultural sector plays a fundamental role in the national economies and food security, but is highly vulnerable to climate variability and

\footnotetext{
*Correspondence: beteozongo@yahoo.fr

${ }^{1}$ University of Dedougou, 03 P. Box BP 176, Dedougou 03, Burkina Faso

Full list of author information is available at the end of the article
}

change. The irregular rainfall distribution is a serious obstacle to rainfed agriculture. Various water harvesting techniques (zaï or tassa, stone rows, halfmoon, filtering dykes, bunds, mulching, etc.) are used by farmers to reduce the impact of the variability, but are not sufficient in the case of a prolonged drought lasting 2-3 weeks $[1,2]$. The farmers' vulnerability to the Sahelian climate and food insecurity increased at the end of the twentieth original author(s) and the source, provide a link to the Creative Commons licence, and indicate if changes were made. The images or other third party material in this article are included in the article's Creative Commons licence, unless indicated otherwise in a credit line to the material. If material is not included in the article's Creative Commons licence and your intended use is not permitted by statutory regulation or exceeds the permitted use, you will need to obtain permission directly from the copyright holder. To view a copy of this licence, visit http://creativecommons.org/licenses/by/4.0/. The Creative Commons Public Domain Dedication waiver (http://creativeco mmons.org/publicdomain/zero/1.0/) applies to the data made available in this article, unless otherwise stated in a credit line to the data. 
century due to an almost $30 \%$ reduction in rainfall concomitant with a population increase [3, 4]. The dry spells continues to affect agricultural productivity, thereby reducing food security which exists when all people, at all times, have physical, social and economic access to sufficient, safe and nutritious food that meets their dietary needs and food preferences for an active and healthy life [5]. Sufficiency of food is focused on the availability of an adequate quantity and quality of food; physical and economic access looks at households and individuals having access to enough food; the security dimension is about food utilization by the body, food safety, risks, shocks, vulnerability, and trade-offs, while the time dimension looks at the stability of food availability, access, and utilization.

According to [6], between 720 and 811 million people in the world faced food insecurity. Considering the middle of the projected range (768 million), 118 million more people were facing hunger in 2020 than in 2019, with estimates ranging from 70 to 161 million. The numbers show enduring and troubling regional inequalities. About one in five people ( 21 percent of the population) was facing hunger in Africa in 2020-more than double the proportion of any other region. This represents an increase of 3 percentage points in 1 year. Sub-Saharan Africa is among the regions most affected by food insecurity, being home to $60 \%$ of the world's food insecure people [5]. In Burkina Faso, food insecurity affects more than $70 \%$ of the population [7, 8]. According to [9], the food insecurity affected $89.5 \%$ of households in the northern region. Therefore, farmers, researchers, governments and global development community are looking for innovative pathways to stabilize or increase rainfed agricultural production and food supply [10].

Supplemental irrigation appears to be a promising way to adapt rainfed agriculture to climate variability and improve agriculture productivity [11-13]. Indeed, theoretical calculations already highlighted the possibility of increasing the productivity of rainfed crops through supplemental irrigation [14-16]. According to [17, 18], if supplemental irrigation were applied to all rainfed cropland, global cereal production could be increased by $35 \%$, the largest potential being in Africa and Asia. Households that grow rainfed crops are willing to practice supplemental irrigation using rainwater harvested in ponds in future agricultural seasons $[19,20]$. These households believe supplemental irrigation is a good way to adapt rainfed agriculture to dry spells and improve food security. Supplemental irrigation is currently being scaled up in Sahelian Africa through several agricultural development programs, yet its profitability and food security contribution are not yet formally known [12, 21 . The recent studies focused only on the impact of supplemental irrigation on yields and the socioeconomic factors of farmers' willingness to adopt it without assessing the costs of ponds and addressing the food security $[15,19,20]$. Practicing supplemental irrigation requires investment upstream for the construction of runoff collection ponds and the purchase of dewatering equipment [22].

The overall aim of this article is to assess the economic profitability of supplemental irrigation using runoff collection ponds in Burkina Faso. The specific objectives are to analyze the contribution of supplemental irrigation to food security and to compare the profitability of different types of ponds dug by the householders on their farms.

According to the literature, numerous definitions and indicators of food security, which, while helping to improve food security knowledge, increase the difficulty in measuring the concept consistently [23-25]. The most widely used and validated food security indicators that dominate the food security measurement debate are focus on: household food insecurity access scale, coping strategy index and dietary diversity score [26, 27]. These indicators offer little consensus on what food security should be [25, 27, 28].

In Sahelian countries, food security largely depends on national cereal and fodder production because more than $80 \%$ people have very limited access to imported food $[11,29]$. Therefore, governments use cereal and fodder needs as indicators of food security in planning and evaluating results of agricultural campaigns following norms of Permanent Inter-states Committee for Drought Control in the Sahel which has proposed consumption standards by country, considering the habits and diversification of food consumption [8]. This approach offers a much finer analysis of the food situation than in the usual approaches [30]. In line with [8], we use cereal and fodder requirements as indicators to analyze the contribution of supplemental irrigation to food security. The criteria for analyzing the profitability of the selected runoff collection ponds are net margin, net present value, the internal rate of return and the payback period [31].

The remainder of the paper is organized as follows. After describing the materials and methods, we present the results and discussions. The conclusions including some policy implications and research limits are provided in the last section.

\section{Materials and methods}

\section{Supplemental irrigation system}

Supplemental irrigation consists of supplying water to crops during the long dry spells that occur during the rainy season, using water stored in a small pond constructed near the field concerned [3, 4]. Supplemental irrigation makes it possible to irrigate a portion of 
farmland dedicated to intensive cultivation. It is based on four principles: (i) the construction of the pond by the farmer and his family with possible support from neighbors; (ii) the collection of runoff water from the start of the rainy season; (iii) the choice of crop; and (iv) practicing irrigation during dry spells in the rainy season. The irrigation equipment proposed here is the pedal pump (Fig. 1).

\section{Study area}

Supplemental irrigation was tested in the provinces of Yatenga and Bam in northern Burkina Faso in this study. The region is characterized by a long dry season from October to May and a short rainy season from June to September. Annual average rainfall varies between 500 and $600 \mathrm{~mm}$. It is particularly irregular and unevenly distributed.

Eleven pilot producers, six producers in Bam province and five in Yatenga province, were selected to practice supplemental irrigation during three rainy seasons (2013-2016) as part of a pilot project supported by the International Development Research Centre (IDRC). The criteria for choosing the producers were mastery of farming techniques, the availability of family labor and access to at least 0.25 ha of farmland for supplemental irrigation, and the absence of wells or watercourses in the vicinity of the farm.

Each farm selected an experimental plot of 0.25 ha and a control plot of 0.25 ha, where the barka corn variety

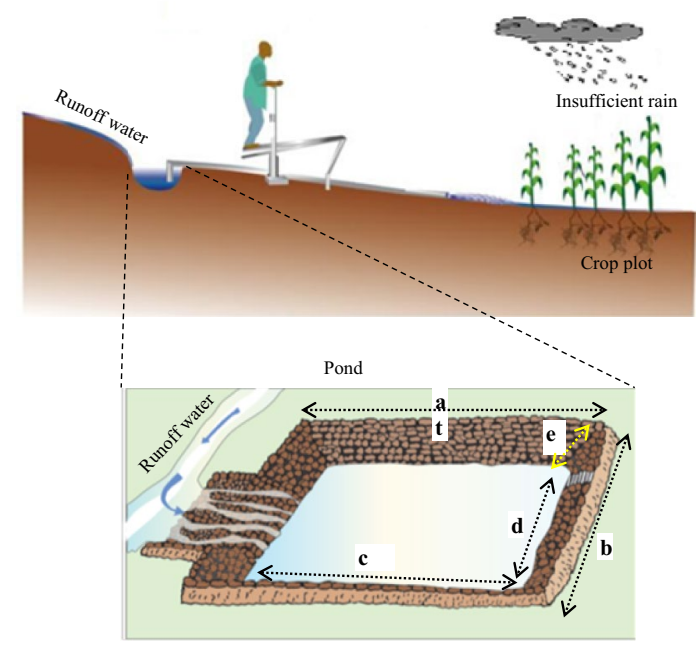

Note: $\mathrm{a}=16.2 \mathrm{~m} ; \mathrm{b}=13 \mathrm{~m} ; \mathrm{c}=15.2 \mathrm{~m} ; \mathrm{d}=12 ; \mathrm{e}=1.6 \mathrm{~m}$; occupied area $=210.60 \mathrm{~m}^{2}$; Maximum volume of stored water: $291.84 \mathrm{~m}^{3}$

Fig. 1 Supplemental irrigation system and dimensioning of the pond to collect runoff water (adapted from [16])
(80 days) was sown. Both the plots belong to the same farmer. Some vegetable crops (local eggplant, pepper) or tobacco were also sown after the corn was harvested in the experimental plot. Seeds, fertilizers and a pedal pump were supplied to each pilot producer for experimentation (Fig. 2).

\section{Food security analysis}

The contribution of irrigation to food security was estimated based on human consumption of cereals and animal consumption of dry matter (fodder). In Burkina Faso, annual consumption of cereals is estimated to be an average of $190 \mathrm{~kg} /$ person, or $0.53 \mathrm{~kg} /$ day [8]. Consumption of dry matter by cattle is evaluated at $5.3 \mathrm{~kg} /$ day per head of cattle (0.85 Tropical Cattle Units) and $1 \mathrm{~kg} /$ day per sheep or goat [32].

The estimated number of additional people $(\mathrm{N})$ that can be fed from the yield obtained from supplemental irrigation in 1 month (30 days) is given by the following formula:

$$
N=\frac{\mathrm{Pdt}_{\mathrm{PE}}-\mathrm{Pdt}_{\mathrm{PT}}}{0.53 \times 30}
$$

where Pdt $\operatorname{PE}_{\mathrm{PE}}=$ yield of the experimental plot $(\mathrm{kg})$ and $\operatorname{Pdt}_{\mathrm{PT}}=$ yield of the control plot $(\mathrm{kg})$. A Student's $T$ test was used to compare the average returns of yields.

The number of additional sheep or goats $(A)$ that can be fed from the yield resulting from supplemental irrigation in 1 month (30 days) is given by the following formula:

$$
A=\frac{\mathrm{MS}_{\mathrm{PE}}-\mathrm{MS}_{\mathrm{PT}}}{5.3 \times 30},
$$

where $\mathrm{MS}_{\mathrm{PE}}=$ dry matter yield in the experimental plot $(\mathrm{kg})$ and $\mathrm{MS}_{\mathrm{PT}}=$ dry matter yield in the control plot $(\mathrm{kg})$.

\section{Profitability assessment}

The gross margin (GM) of the experimental plots was estimated as the difference between the gross product (GP) and the input cost (IC) [31]:

$$
\mathrm{GM}=\mathrm{GP}-\mathrm{IC} .
$$

GB was obtained by multiplying the quantity of corn grain and corn fodder by their market price. Purchased inputs for farmers included fertilizers (nitrogen, phosphorus and potassium: $200 \mathrm{~kg} / \mathrm{ha}$; urea: $50 \mathrm{~kg} / \mathrm{ha}$ ) and improved maize seeds $(20 \mathrm{~kg} / \mathrm{ha})$. The cost of each input was estimated as the quantity of an input multiplied by its purchase price. Hired labor has not been employed for any agricultural activities. The difference between GM of the experimental plot and the control plot represents 


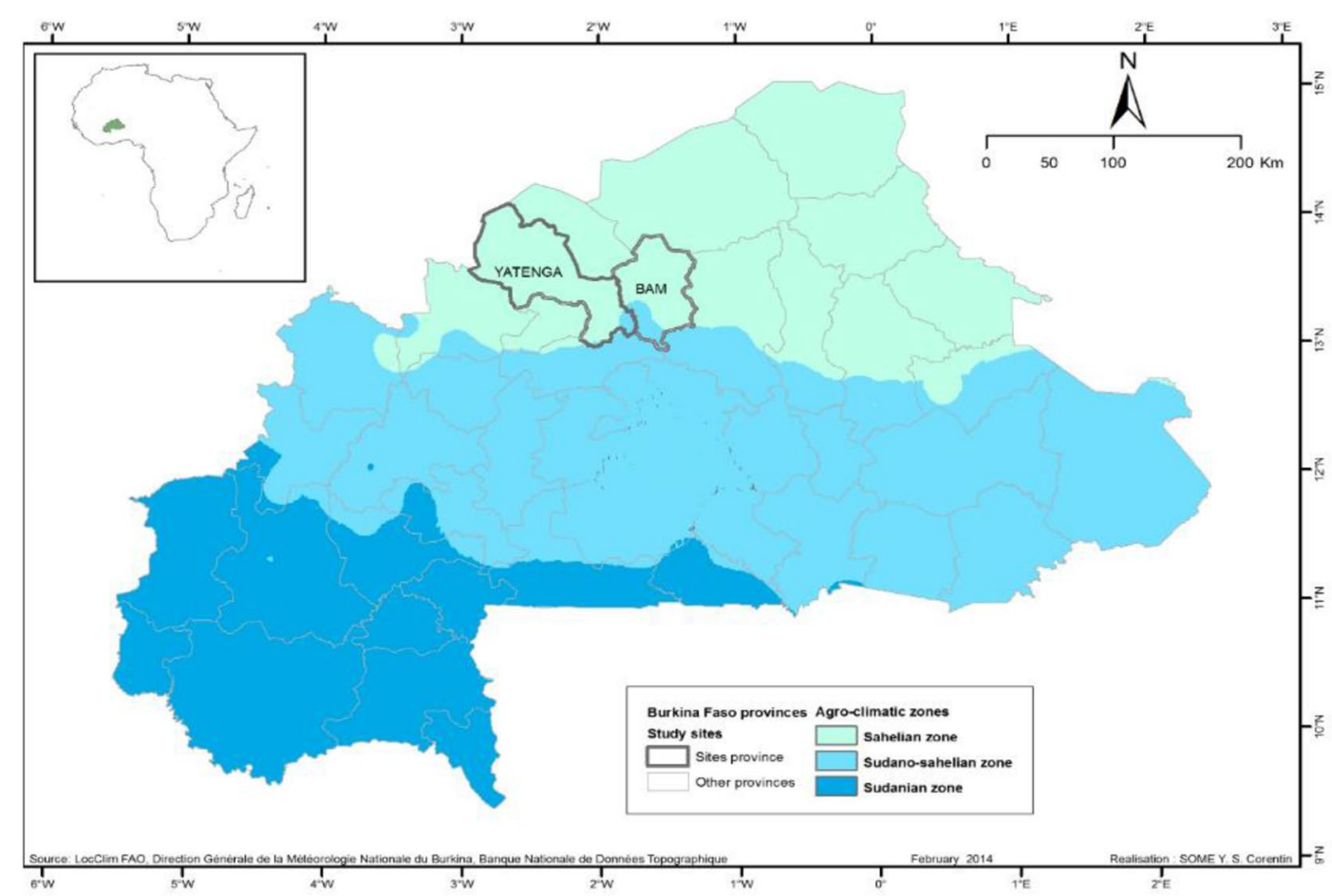

Fig. 2 Map of the agro-climatic zones in Burkina Faso showing the provinces of Yatenga and Bam

the monetary profit gained by practicing supplemental irrigation.

The net profit margin (NPM) was obtained by deducting input costs (IC) and fixed costs (FC) from the gross product (GP) or by deducting the fixed costs (FC) from the gross margin (GM). Annual FCs include annual depreciation of the pond and of the pump. A straightline depreciation rate was used. The life span of the pond was set at 15 years and that of the irrigation equipment at 5 years. The farmers' family labor ensured the land preparation, plowing, sowing and harvesting in both plots. The cost of farmers' labor is not included in the FC.

$$
\mathrm{NPM}=\mathrm{GP}-\mathrm{IC}-\mathrm{FC}=\mathrm{GM}-\mathrm{FC} .
$$

If the net margin is positive, it is concluded that the gross product covers all the fixed costs and that the agricultural production activity is economically attractive. On the other hand, if the net margin is negative, then the gross product cannot cover the costs. In this case, the production is not economically attractive.

To analyze the profitability of the supplemental irrigation system, we considered the average production of corn in the three agricultural seasons. The criteria used for the analysis were net present value (NPV), internal rate of return (IRR) and payback period (PBP) [33].

The NPV was evaluated as the sum of all the discounted benefits obtained by the difference between the target product and the cost of the inputs and the fixed cost of the supplemental irrigation equipment. These charges are linked to the construction of the pond and the purchase of dewatering equipment. Formally, at the end of 15 crop years (agricultural campaigns), the NPV is given by the following expression:

$$
\mathrm{NPV}=\sum_{t=1}^{15} \frac{\mathrm{GP}_{t}-\mathrm{IC}_{t}-\mathrm{FC}_{t}}{(1+r)^{t}}
$$

where $t$ is the crop year and $r$ is the discount rate estimated to be $12.5 \%$ according to the credit institutions from which farmers can sometimes obtain credit. Note that when planning at a 15-year horizon, the pump will have to be renewed three times given that its life span is fixed at 5 years. When the NPV is positive, the investment is deemed to be economically profitable, and the project deserves to be undertaken. On the other hand, if it is negative, the investment is not profitable and supplemental irrigation should not be practiced, as it will result in a loss.

The IRR was assimilated in the rate that cancels the NPV. It is determined by the following equation:

$$
\sum_{t=0}^{15} \frac{\mathrm{GP}_{t}-\mathrm{FC}_{t}-\mathrm{IC}_{t}}{(1+r)^{t}}=0 .
$$


The investment required for the implementation of supplemental irrigation devices is appropriate when the IRR is higher than the discount rate; otherwise, there is no need to invest.

The PBP is the time $d$ necessary for the net benefits to balance the investment costs required to acquire the supplemental irrigation system. It is formulated according to the expression:

$$
\sum_{t=0}^{d} \mathrm{GP}_{t}=\sum_{t=0}^{d}\left(\mathrm{CI}_{t}+\mathrm{FC}_{t}\right) .
$$

The profitability of supplemental irrigation system depends on the type of pond. Note that the cost of purchasing the supplemental irrigation system includes the cost of household labor in the form of a salary.

\section{Results}

\section{Yield assessment}

As shown in Fig. 3a, the average yields of maize obtained at the end of the 2013-2014 cropping year were estimated at $2.46 \mathrm{~T} /$ ha in the experimental plot and $1.71 \mathrm{~T} /$ ha in the control plot. In the 2014-2015 campaign, yields were evaluated at $1.88 \mathrm{~T} /$ ha and $0.92 \mathrm{~T} / \mathrm{ha}$, respectively, in the experimental and control plot. In the 2015-2016 cropping year, the yields obtained from the experimental plot were $2.76 \mathrm{~T} /$ ha versus $1.78 \mathrm{~T} / \mathrm{h}$ a from the control plot. The Student's $T$ test revealed a significant difference between the average yields of the experimental plot and the control plot at the end of the 2013-2014 cropping year $(t=4.134 ; p=0.003), 2014-2015(t=6.656$; $p=0.000)$ and $2015-2016(t=4.844 ; p=0.001)$. The difference in average maize yields on the experimental plots between years is related to the variation of intervals and doses of supplemental irrigation practiced by farmers. On the other hand, on the control plots, this difference in yield is explained by variation in the duration of dry spells during campaign seasons.

Yields of fodder obtained from the experimental plot were higher than yields obtained from the control plot (Fig. 3b). The average yields obtained in the 2013-2014 cropping year were estimated at $3.47 \mathrm{~T} / \mathrm{ha}$ in the experimental plot and 2.42 in the control plot. In 2014-2015, the experimental plot and the control plot produced 2.69 and $1.58 \mathrm{~T} / \mathrm{ha}$, respectively. In the 2015-2016 campaign, yields from the experimental plot and the control plot were $2.93 \mathrm{~T} /$ ha and $2.26 \mathrm{~T} / \mathrm{ha}$, respectively. Statistical analyses revealed a significant difference between the yields in the experimental plot and in the control plot after the 2013-2014 cropping year $(t=3.405 ; p=0.006)$, 2014-2015 $(t=3.942 ; \quad p=0.002)$ and 2015-2016 $(t=3.536 ; p=0.008)$.

\section{Contribution to food security}

The contribution of corn production to food security varied with the experimental plot (Fig. 4a). The average yield of corn from the experimental and control plots in the 2013-2014 campaign covered the cereal needs of, respectively, 39 and 27 people for 1 month. Those of the experimental and control plots in 2014-2015 satisfied the cereal needs of, respectively, 38 and 14 people. In the 2015-2016 campaign, the corn yield from the experimental plot covered the cereal needs of 43 people and those of the control plot, 28 people. It thus appears that the surplus yields obtained from the experimental plot in 2013-2014, 2014-2015 and 2015-2016 would feed between 12 and 24 additional people in the households per month compared to the control plot. These surpluses can meet the cereal needs of the average household of five people in the study area for at least 3 months.

The number of cattle fed with fodder obtained from the experimental plot in 1 month was estimated at nine in

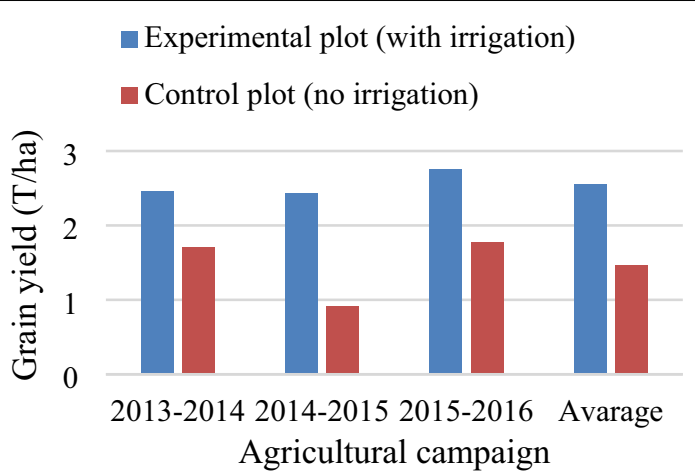

a) Grain yields

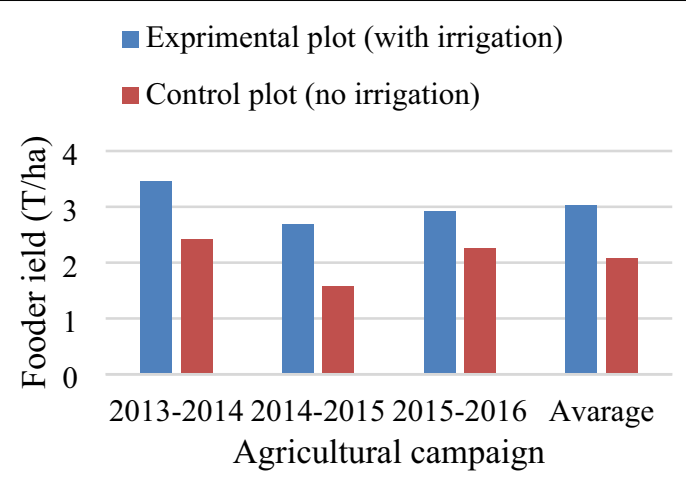

b) Fodder yields

Fig. 3 Comparison of maize yields for 2013-2016 


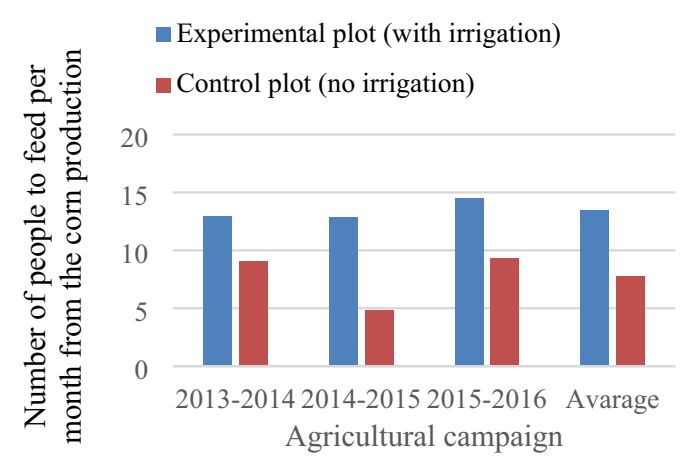

a) Cereal requirement

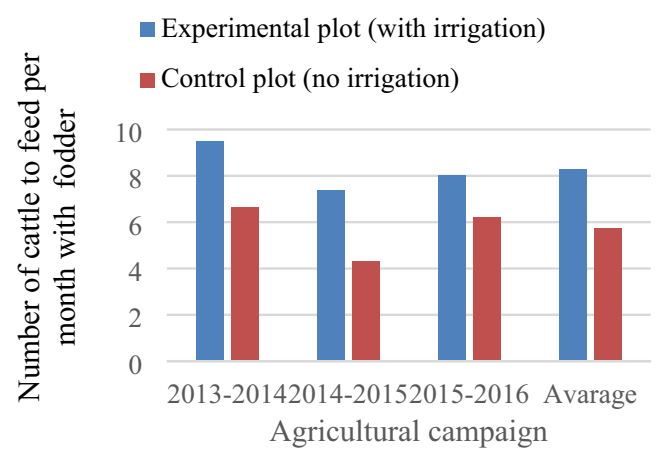

b) Feed requirement of livestock

Fig. 4 Food security contribution

2014-2015, seven in 2014-2015 and eight in 2015-2016 (Fig. 4b). The number of cattle fed fodder obtained from the control plot was estimated at seven in 2013-2014, four in 2014-2015 and six in 2015-2016. Thus, compared to the control plot, the number of additional cattle fed with the fodder from the experimental plot was two in 2013-2014, three in 2014-2015 and two in 2015-2016. This additional number shows that the practice of supplemental irrigation on corn is advantageous for livestock.

\section{Gross margin}

The gross margin obtained from average corn yields in the 2013 to 2016 agricultural campaigns differed between the experimental plot and control plot (Table 1). The GM was evaluated at FCFA 77,634 (US\$ 134.57) for the experimental plot and at FCFA 50,632 (US\$ 87.76) for the control plot at the end of the 2013-2014 campaign. The GM of the experimental and control plot in the 20142015 campaign was estimated at, respectively, FCFA 23,455 (US\$ 40.66) and FCFA 72,263 (US\$ 125.26). In 2015-2016, the GM was estimated at FCFA 82,513 (US\$ 143.03) for the experimental plot and FCFA 51,375 (US\$ 89.05) for the control plot.

Supplemental irrigation of rainfed corn produced a surplus of FCFA 27,002 (US\$ 46.80) in 2013-2014, FCFA 48,809 (US\$ 84.60) in 2014-2015, and FCFA 31,138 (US\$ 53.97) in 2015-2016. The surplus generated in 20142015 was higher than in 2013-2014 and 2015-2016. The average increase in GM was FCFA 35,649 (US\$ 61.79) per campaign. Since input costs remained similar between years, the difference can be explained by the differences in grain and forage yield in the three seasons.

Many pilot producers sowed a second crop after corn (eggplant, tobacco, pepper, sesame, okra, cowpea, soy) using the water collected in the ponds during the rainy season (Table 2). The released average GM was evaluated at FCFA 19,178 (US\$ 33.24) in 2013-2014, FCFA 17,450 (US\$ 30.25) in 2014-2015, and FCFA 194,550 (US\$ 337.23) in 2015-2016. The cultivation of tobacco by some pilot farmers explains the significant increase in GM in the 2015-2016 campaign.

Taking corn and secondary crops into account, the difference between the GM of the experimental and control plots was estimated at FCFA 46,180 (US\$ 80.05) in the 2013-2014 agricultural campaign, FCFA 115,067 (US\$ 199.45) in 2014-2015 and FCFA 256,825 (US\$ 445.17) in 2015-2016 (Fig. 5). The average GM was estimated at FCFA 178,423 (US\$ 309.26) per campaign. These results confirm that supplemental irrigation of rainfed crops could be a profitable way to mitigate the effects of climate variability and climate change in the Sahel.

\section{Net profit margin \\ Cost of building the ponds}

All the ponds were built by the farmers' families and volunteer neighbors. The equipment used for the construction of these ponds included picks, crowbars, shovels, wheelbarrows, wire mesh plus rubble and gravel. Cement, clay and tarpaulin for waterproofing was only needed in some ponds whose underlying soils were too porous. The type of waterproofing material explains the difference in the cost of the ponds. Depending on the investment cost, there are four categories of ponds (Table 3):

Ponds whose bottom and walls are not waterproofed. This type of pond was constructed in clayey or lateritic soils (Fig. 5a, b) characterized by low seepage. After excavation, the walls and bottom of the pond received no coating since the type of soil prevents leakage of the collected runoff water. The investment cost of this type of pond was evaluated at FCFA 


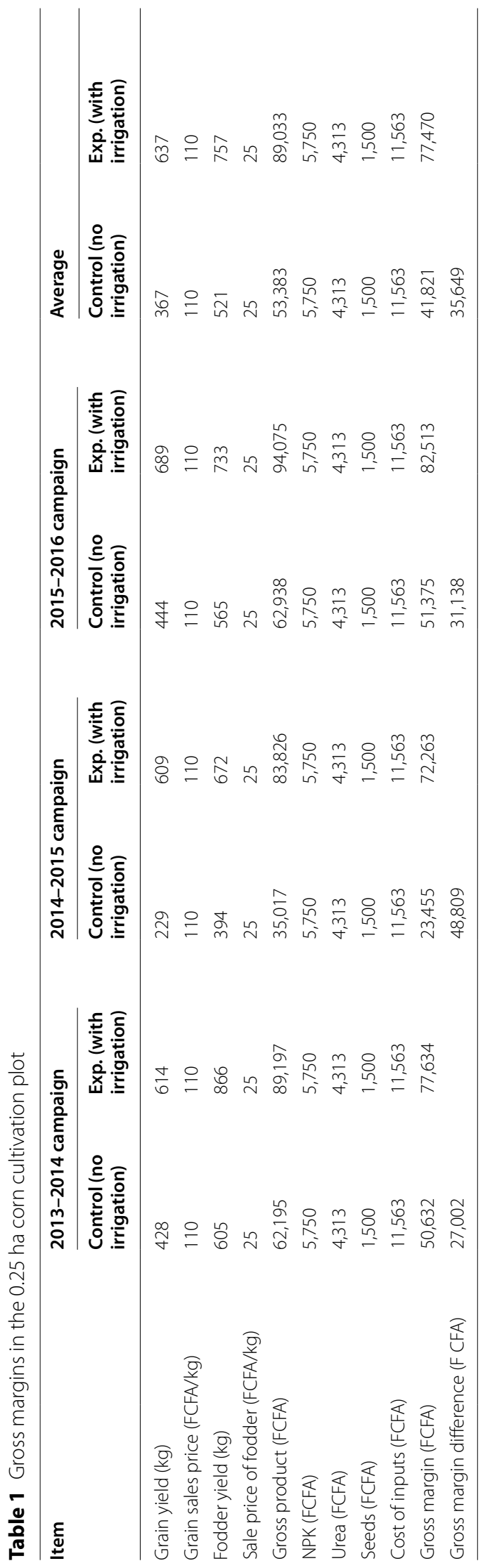


Table 2 Gross margins of secondary crops under supplemental irrigation

\begin{tabular}{lllll}
\hline Secondary crops & \multicolumn{5}{l}{ Gross margin (FCFA) } \\
\cline { 2 - 5 } & $\begin{array}{l}\text { 2013-2014 } \\
\text { Campaign }\end{array}$ & $\begin{array}{l}\text { 2014-2015 } \\
\text { campaign }\end{array}$ & $\begin{array}{l}\text { 2015-2016 } \\
\text { campaign }\end{array}$ & Average \\
\hline Eggplant & 5850 & 2000 & 4050 & 16,200 \\
Tobacco & & 8900 & 130,000 & 69,450 \\
Pepper & 4928 & 1500 & 6800 & 4409 \\
Sesame & & 800 & & 800 \\
Okra & & 3250 & 14,000 & 8625 \\
Cowpea & 8400 & 1000 & & 4700 \\
Soy & - & - & 3000 & 3000 \\
Gross margin (F CFA) & 19,178 & 17,450 & 194,550 & $\mathbf{7 7 , 0 5 9}$ \\
\hline
\end{tabular}

784,900 (US\$ 1,360.52) when the workforce is paid wages. When the opportunity cost of the plot and annual maintenance were added, the cost of the pond reached FCFA 802,900 (US\$1,391.72).

pond with a waterproof base of clay and cemented waterproof walls (Fig. 5c). This type of pond was constructed on clayey soil characterized by more seepage than in clayey or lateritic soils. The seepage is mainly vertical, i.e. through the bottom of the pond. To limit it, the bottom of the pond is coated with clay transported to the site. Assuming household labor is paid, the construction cost was evaluated at FCFA 922,900 (US\$ 1599.73). When the opportunity cost of the land and the annual maintenance of the pond were added, the total cost was FCFA 940,900 (US\$ 1630.93). It is the cost of cement and clay for waterproofing the walls and the bottom that increase the cost of this type of pond.

a pond with a tarpaulin bottom and waterproofed cement walls (Fig. 5d). This type of pond was con- structed in sandy loam soils characterized by a higher seepage rate. To limit this seepage, cement and a tarpaulin were purchased to coat the walls and the bottom of the pond. The cost was evaluated at FCFA 1,710,900 (US\$ 2964.06) when the workforce is paid. When the opportunity cost of the land and the annual maintenance of the pond were added, the total cost was FCFA 1,728,900 (US\$ 2996.82).

a pond with both the bottom and walls waterproofed with a tarpaulin (Fig. 5e). This type of pond was constructed in sandy soils with a high rate of seepage. To avoid this heavy seepage, a tarpaulin covered both the walls and the bottom of the pond. Its construction required an investment of FCFA 2,191,900 (US\$ 3799.37) assuming that the labor for the excavation is paid in cash. When the opportunity cost of the land and the annual maintenance were added, the cost was evaluated at FCFA 2, 201, 900 (US\$ 3816.70). This pond is the most expensive (Fig. 6).

\section{Cost of irrigation equipement}

The pump kit includes a foot pump, bearings, valves, a strainer, a cup, spare parts and suction and discharge pipes (Table 4). The cost of the kit is estimated at FCFA 139,476 (US\$241.76). The purchase of the foot pump and suction hoses represents $70 \%$ of the total acquisition cost. The pump operates on human energy using two pedals via a suction and delivery system (Fig. 5f). It can lift water up to $7 \mathrm{~m}$ high and discharge it at a distance of $200 \mathrm{~m}$ on flat ground. Its average flow rate is $3300 \mathrm{~L}$ per hour depending on the intensity of pedaling. It can irrigate $2500 \mathrm{~m}^{2}$ (0.25 ha) in $2 \mathrm{~h}$.

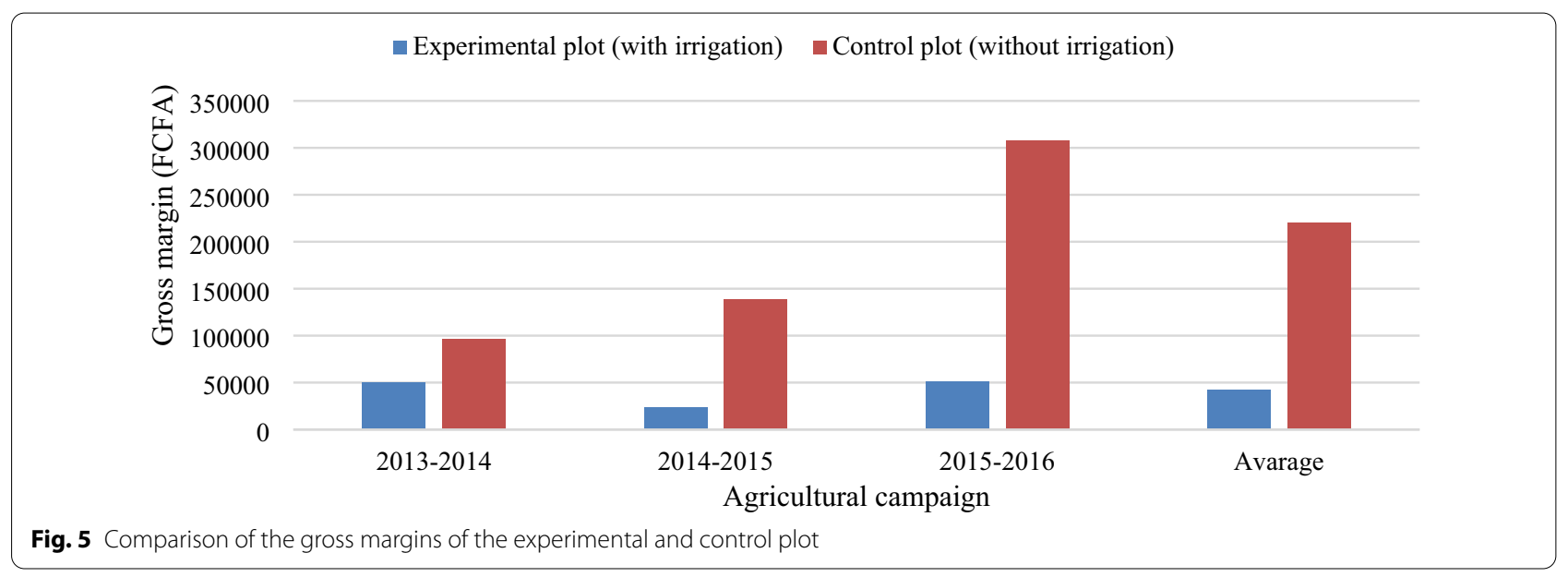




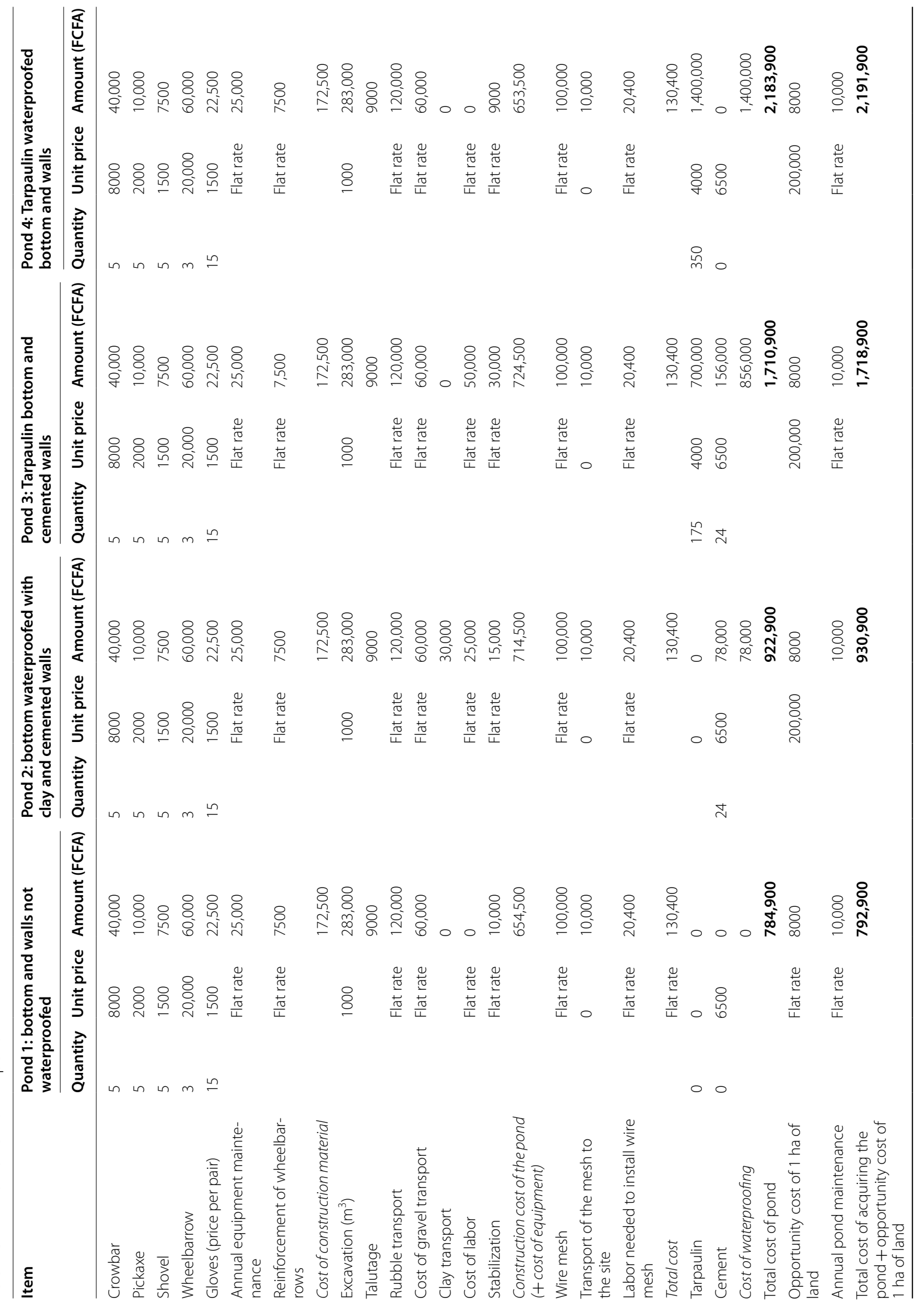




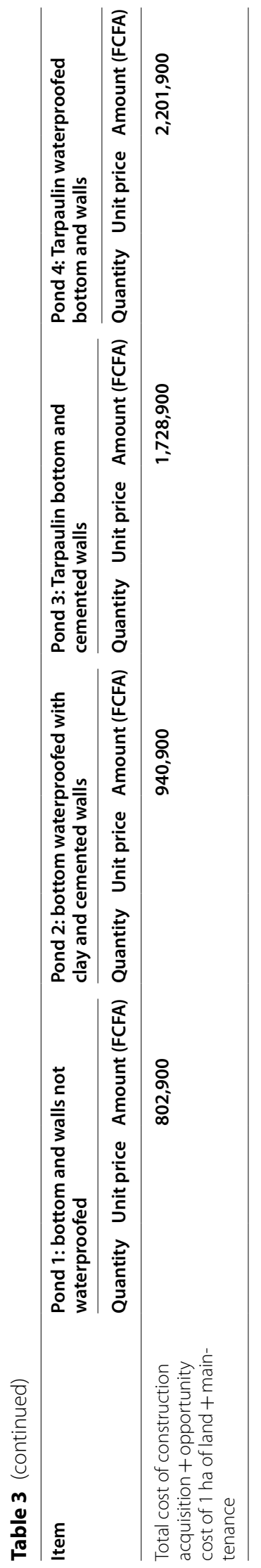




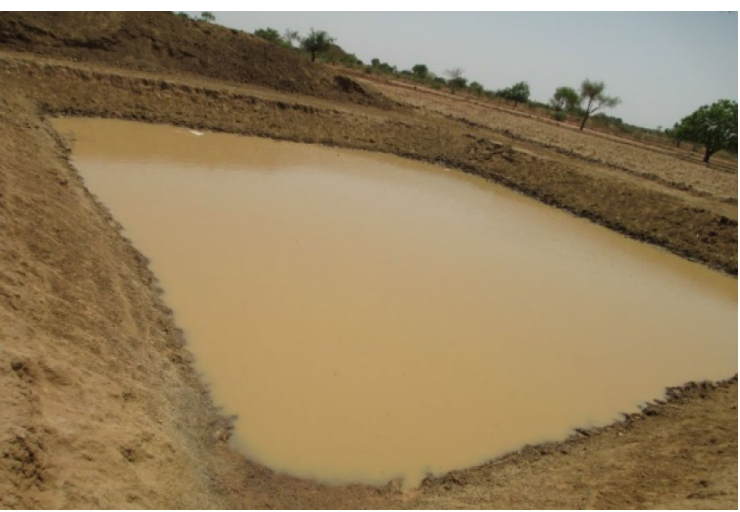

a) Pond with bottom and un-waterproofed walls on clay soil in Bam province

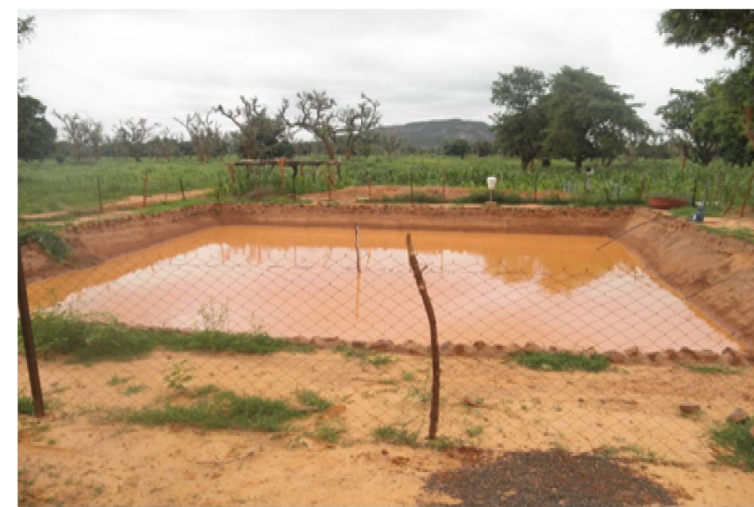

c) Pond in impermeable clay with waterproofed cement walls in Bam province

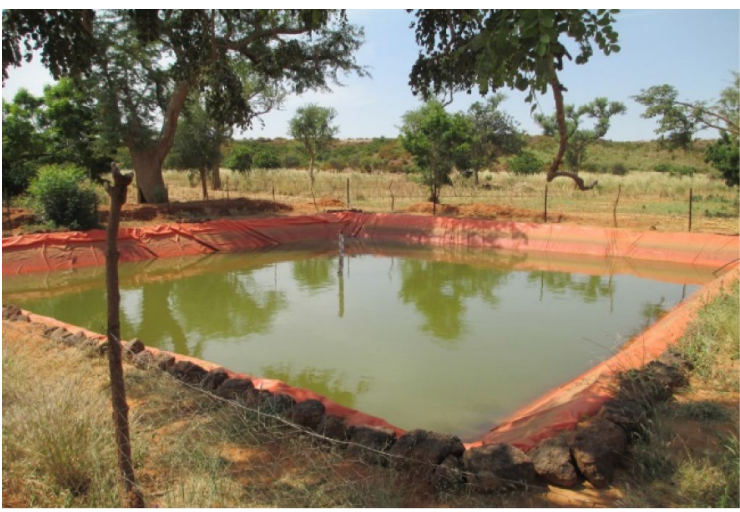

e) Pond with bottom and walls waterproofed with a tarpaulin in sandy soil in Bam province

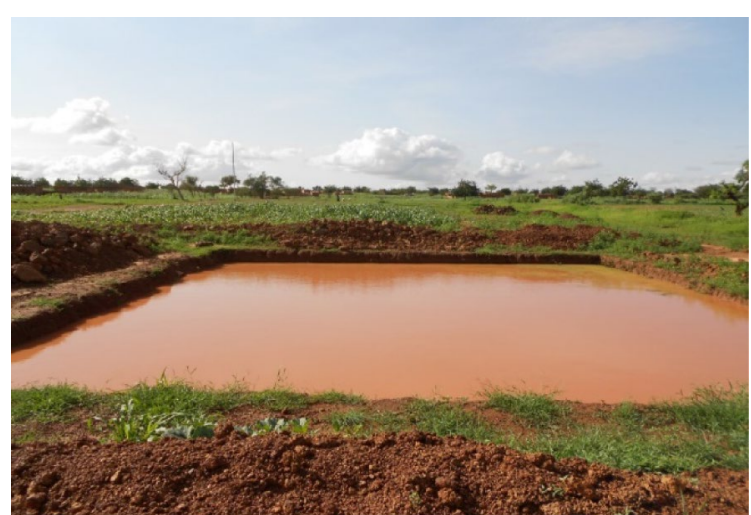

b) Pond with bottom and un-waterproofed walls on lateritic soil in Yatenga province

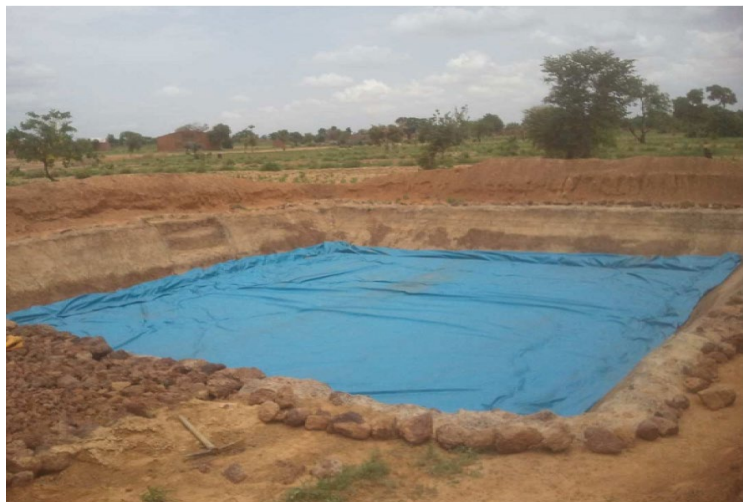

d) Pond with covered bottom and waterproofed cement walls in Yatenga province

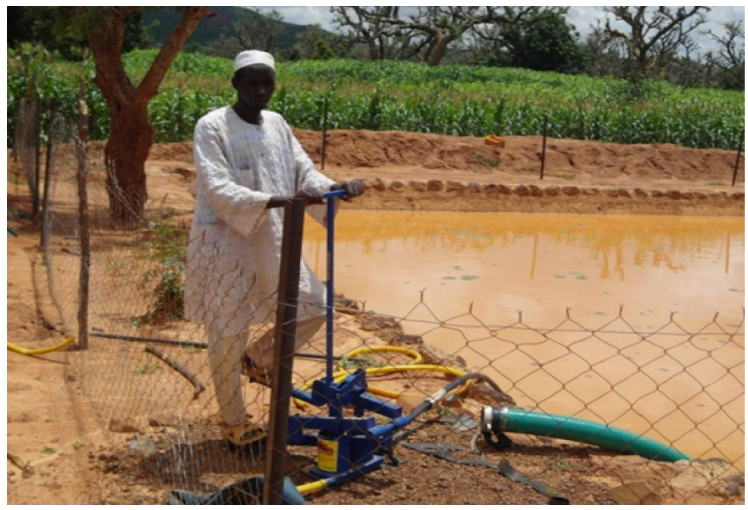

f) Piloting supplemental irrigation using a pedal pump in Bam province

Fig. 6 Types of ponds and irrigation equipment

\section{Analysis of the profit margin}

For supplemental irrigation, the fixed costs are determined by the sum of the annual depreciation of each type of pond and the dewatering equipment. The annuity is obtained by multiplying the cost of each type of pond or dewatering equipment by a linear depreciation rate. The linear depreciation rate is calculated by dividing 100 by the expected life of each pond or dewatering equipment (Table 5). The life span was estimated at 15 years for each pond and at 5 years for the dewatering equipment. 
Table 4 Cost of dewatering equipment

\begin{tabular}{llll}
\hline Item & Quantity & Unit price (FCFA) & Amount (FCFA) \\
\hline Foot pump & 1 & 49,500 & 49,500 \\
26 m elbows & 1 & 30,00 & 3,000 \\
32 m suction hose & 1 & 39,00 & 3,900 \\
26 m discharge hose & 1 & 562,50 & 56,250 \\
Pedal bearings & 1 & 300 & 300 \\
Tilt bearings & 1 & 300 & 300 \\
Leak valve & 1 & 200 & 200 \\
Strainer & 1 & 4,000 & 4,000 \\
Cup & 1 & 500 & 500 \\
Discharge/suction valve & 1 & 250 & 250 \\
VAT (18\%) & 1 & 21,276 & 21,276 \\
Cost of irrigation equipment (FCFA) & - & 139,476 \\
\hline
\end{tabular}

Table 5 Estimated depreciation of ponds and dewatering equipment

\begin{tabular}{lcllr}
\hline Item & Cost of construction (FCFA) & Estimated life & Depreciation rate & Annuity (FCFA) \\
\hline Pond 1 & 784,900 & 15 & $6.67 \%$ & 52,327 \\
Pond 2 & 922,900 & 15 & $6.67 \%$ & 61,527 \\
Pond 3 & $1,710,900$ & 15 & $6.67 \%$ & 114,060 \\
Pond 4 & $2,191,900$ & 15 & $6.67 \%$ & 145,593 \\
Pedal pump and accessories & 139,476 & 5 & $20 \%$ & 27,895 \\
\hline
\end{tabular}

The analysis shows that the practicing supplemental irrigation from a pond with un-waterproofed walls and from a pond with only a waterproof clay bottom and cemented walls guarantee a positive net margin (Table 6). In other words, the gross product covers the fixed costs, and the practice of supplemental irrigation is thus profitable at a 15-year horizon. Supplemental irrigation is not profitable using a pond with a bottom covered with tarpaulin and cemented walls or a pond with a both bottom and walls covered with tarpaulin since the net margin is negative. By comparing the ponds, the costs of waterproofing, transporting the clay to the site, stabilization and masonry explain the respective profitability of the different ponds. Apart for these items, the costs of the other components of the ponds are similar.

\section{Analysis of profitability}

When the bottom and walls are not waterproofed The NPV is positive from 5 to $15 \%$ discount rates and becomes negative from $20 \%$ (Table 7). The IRR is evaluated at $19.5 \%$ and the PBP at a 7 -year horizon (Table 8 ). These results show that the practice of supplemental irrigation using a pond whose bottom and walls are not waterproofed is a viable innovation for agricultural households, since the NPV is positive for a discount rate of up to $15 \%$. This practice can be adopted since the IRR is higher than the fixed interest rate (12.5\%) charged by banks in Burkina Faso. Ponds dug in clayish or lateritic soils thus tend to be profitable.

Ponds with a waterproofed clay bottom and waterproofed cement walls display a positive NPV of $5 \%-15 \%$, an IRR estimated at $15.29 \%$ and a PBP of 7 years (Tables 7 , 8). From the above, supplemental irrigation from a pond with a waterproofed clay bottom and cement walls proves to be a viable agricultural innovation that can be adopted by farmers, since the NPV is positive for a discount rate of between 5 and $15 \%$ and the IRR exceeds the interest rate charged by the banks (12.5\%). The construction of ponds in clayey-loam soils is a profitable innovation for supplemental irrigation on rainfed corn over 15 agricultural campaigns.

Pond with a tarpaulin bottom and waterproofed cement walls: have a negative NPV from $5 \%$ discount, an IRR estimated at $4.5 \%$ and a PBP of 11 years (Tables 7,8 ). These results suggest that practicing supplemental irrigation of rainfed corn using a pond built in sandy-silty is not a viable innovation beyond $5 \%$ discount or is only recommended insofar as the IRR is lower than that fixed 


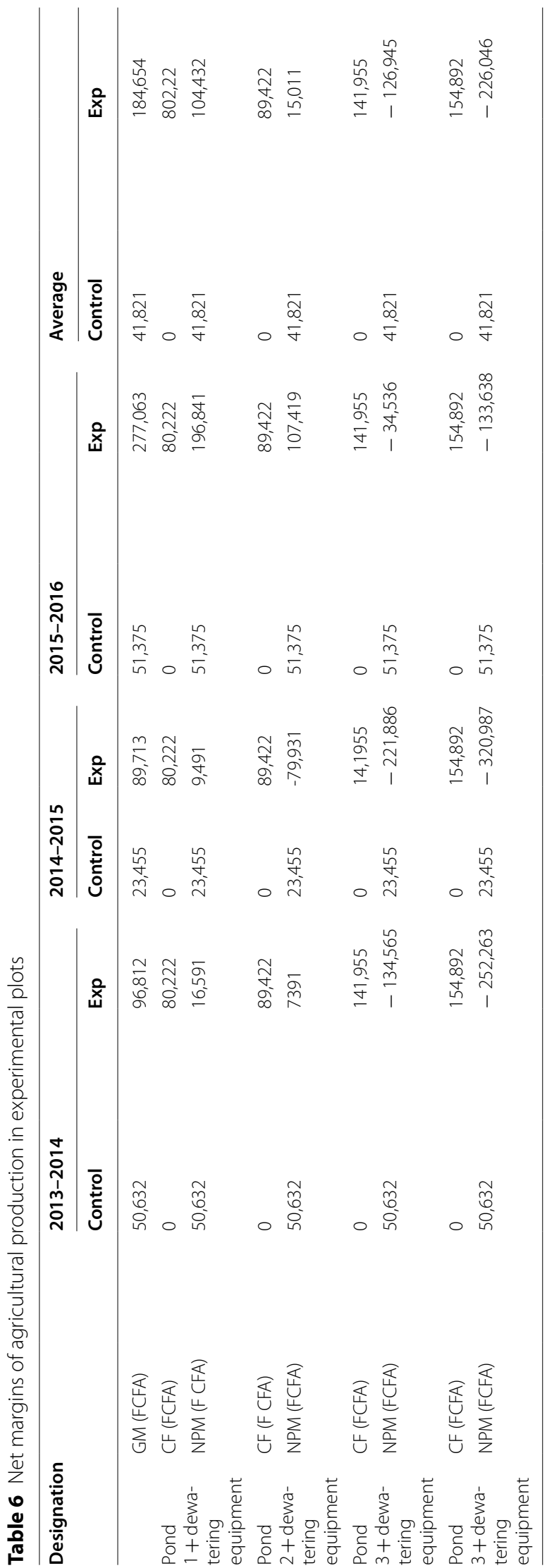


Table 7 IRR and NPV of the supplemental irrigation system on 0.25 ha of corn

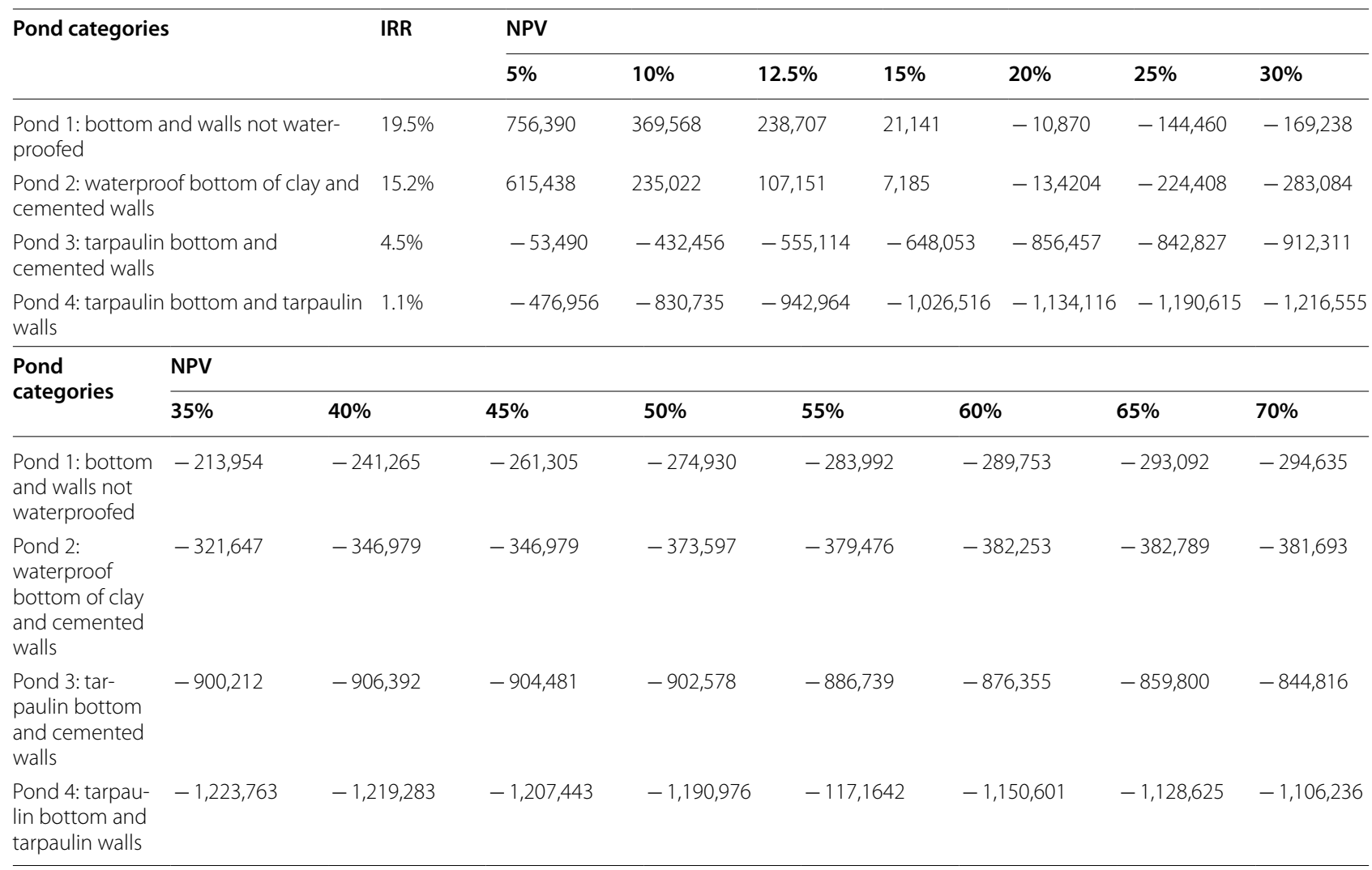

by the banks (12.5\%). It is profitable only after 15 years, corresponding to 15 agricultural seasons

Pond with bottom and walls waterproofed with tarpaulin: The NPV is negative from $5 \%$ discount. The IRR is estimated at $1.1 \%$ and the PBP at 14 years (Tables 7,8 ). Under these conditions, constructing this type of pond for supplemental irrigation in sandy soils is not profitable for agricultural households even after 15 rainfed corn campaigns. In fact, the NPV remained negative, and the IRR was lower than the bank interest rate (12.5\%).

\section{Discussion}

The results obtained in the experimental plots underline the importance of supplemental irrigation to produce corn in the rainy season. Irrigation increases corn yields whatever the type of agricultural campaign. The increase in grain yields from the experimental plots compared to the control plots was $0.75 \mathrm{~T} /$ ha $(43.47 \%)$ during the 2013-2014 campaign, $1.45 \mathrm{~T} /$ ha $(166.32 \%)$ in $2014-$ 2015 and 0.98 T/ha (55.21\%) in 2015-2016. Supplemental irrigation can thus increase the average corn yield by $1.08 \mathrm{~T} /$ ha (averaged yields in the three agricultural seasons), or $88.34 \%$. These results are comparable to those of other studies [34]. Supplemental irrigation at crops critical growth stage increase more grain yield [17, 35]. In Morocco, Merabeta and Boutiba [36] showed that irrigation of rainfed wheat can produce grain yields of between 5.4 and $5.9 \mathrm{~T} /$ ha versus 1.5 and $3 \mathrm{~T} /$ ha for controls. This more than $100 \%$ increase in yields led the governments of Tunisia and Morocco to consider the respective developments of more than 23,000 and 30,000 ha of supplemental irrigation [37]. In Burkina Faso, Somé [15] showed that supplemental irrigation of sorghum increased sorghum yields by $10 \%-85 \%$ depending on the agricultural season. However, the results of the study by Barron and Okwach [38] in Kenya showed little impact of irrigation on corn yields when rainfall is fairly regularly distributed over the rainy season. From the analysis of previous studies, the impact of supplemental irrigation on yields depends on the importance of dry spells [22, 23, 36].

The increase in corn yields enabled by supplemental irrigation contributes to food security through increasing grain consumption by the households. It makes it possible to meet the monthly demand for 17 extra months for one person or covers the needs of five people for 3 months. These results suggest that supplemental irrigation relevance for food security in line with the norms of Permanent Inter-states Committee for Drought 


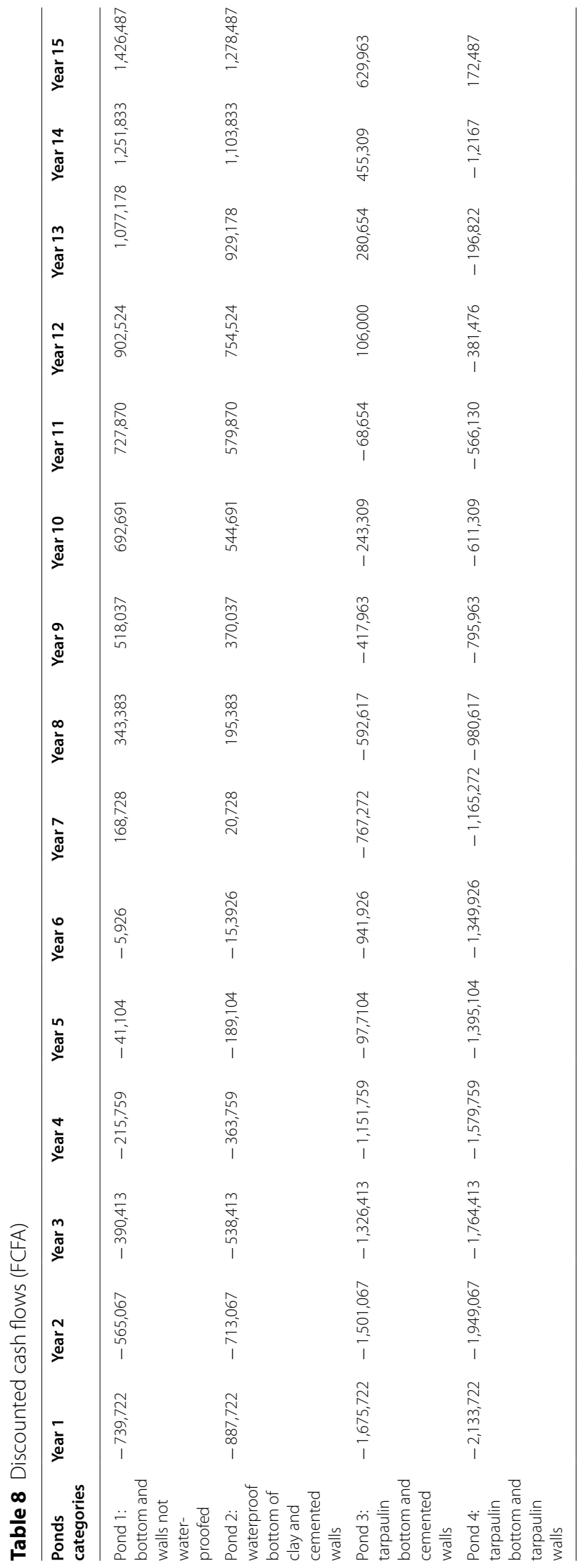


Control in the Sahel [8]. This is why Sahelian countries have adopted policies to popularize the practice of supplemental irrigation in order to reduce the effects of dry spells on agricultural production and improve food security $[39,40]$. In these countries, supplemental irrigation helps farmers to adapt to climate change insofar as it makes it possible to increase agricultural production to meet the food needs of populations in dry years [17]. Farmers readily can adopt supplemental irrigation once they are convinced it is reduces food insecurity [41]. But this practice is still rare in the Sahelian countries of West Africa. Research has long remained at the experimental stage in research stations $[42,43]$.

Investing in supplemental irrigation can have a significant impact on food security However, this study found that supplemental irrigation from a farm pond is profitable under certain conditions. First, it depends on the types of soil and subsoil in which the pond is dug. Ponds dug in clay or lateritic and clay-silt soils are profitable over a period of 15 years, i.e., 15 agricultural campaigns. Panigrahi et al. [44] found this payback period to be acceptable for this type of hydraulic infrastructure. These authors showed that the ponds were economically profitable in 16 agricultural seasons. However, ponds constructed in sandy loam soils require some investments to reduce seepage. These investments include to the purchase of cement or tarpaulin to waterproof the walls and the bottom of the pond. Given most Sahelian farmers' very limited access to credit, a credit program or a subsidy may be required for the construction of the ponds [17].

\section{Conclusions}

This study has shown that the extra corn yield obtained with supplemental irrigation from farm ponds can meet the monthly cereal needs of at least 17 people and generate an additional GM of FCFA 178,48 (US\$ 309.26) per campaign compared to rainfed crops. The estimate of the NPV, from IRR and PBP showed that the profitability of supplemental irrigation in 15 agricultural seasons depends on the type of ponds constructed. Here, we demonstrated the cost-effectiveness of supplemental irrigation for corn yields.

However, the study has some limitations. It does not take the dynamic nature of intensity and variability of precipitation over 15 years estimated period and risk of water-borne diseases and drowning (people and animals). Water productivity has not assessed to the extent that farmers have been allowed to practice irrigation when they observe water requirement for maize. For this, the irrigation doses could not be evaluated.
Moreover, a subsidy or credit policy will be needed for the construction of ponds to facilitate the adoption of supplemental irrigation in Burkina Faso. Irrigation strategies to optimize agricultural income remain a field of research to be explored. It seems necessary to support the up-front cost of the pond with a subsidy or a credit program in order to facilitate the adoption of supplemental irrigation on agricultural holdings. But in Sahelian countries, farmers have little access to credit. Experiences of food for work are now frequent and make it possible to mobilize labor for the construction of small agricultural infrastructures. The implementation of such a policy would stimulate the adoption of supplemental irrigation on a larger scale and help reduce food insecurity.

\section{Abbreviations}

GM: Gross margin; NPV: Net present value; IRR: Internal rate of return; PBP: Payback period.

\section{Acknowledgements}

We thank the field team for their dedication and the participating rural households for their candor.

\section{Authors' contributions}

All authors provided substantial input into the manuscript, and SF processed, analyzed and interpreted the data and led the manuscript writing process. All authors read and approved the final manuscript.

\section{Funding}

This study was made possible by the support of the International Development Research Centre (IDRC) of Canada.

\section{Availability of data and materials}

Please contact the corresponding author for data requests.

\section{Declarations}

Ethics approval and consent to participate

Not applicable.

\section{Consent for publication \\ Not applicable.}

\section{Competing interests}

The authors declare that they have no competing interests.

\section{Author details \\ ${ }^{1}$ University of Dedougou, 03 P. Box BP 176, Dedougou 03, Burkina Faso. ${ }^{2}$ Rural Development and Economic United, University of Liege, P. Box 5030, Gem- bloux Agro-Bio TechGembloux, Belgium. ${ }^{3}$ Centre for International Cooperation in Agricultural Research for Development, 73 Rue Jean-François Breton TA C-90/15, 34398 Montpellier Cedex 5, France. ${ }^{4}$ International Finance Coopera- tion, Soil and Water Platform, Ouagadougou, Burkina Faso. ${ }^{5}$ International Institute for Water and Environmental Engineering (2iE), P. Box 594, Ouagadou- gou 01, Burkina Faso. ${ }^{6}$ United Nations University Institute for Natural Resources in Africa, Toronto, Canada. ${ }^{7}$ Department of Economics and Management, University Ouaga II, Ouagadougou, Burkina Faso. ${ }^{8}$ Institute for Environmental and Agricultural Research, 01 P. Box 476, Ouagadougou 01, Burkina Faso. ${ }^{9}$ Institute for Rural Development, University Nazi Boni, 01 P. Box 1091, Bobo Dioulasso 01, Burkina Faso.}


Received: 16 November 2020 Accepted: 11 November 2021

Published online: 18 January 2022

\section{References}

1. Roose E, Kaboré V, Guénat C. Zai practice: a west african traditional rehabilitation system for semiarid degraded lands, a case study in Burkina Faso. Arid Soil Res Rehabil. 1999:13:343-435.

2. Zongo B, Diarra A, Barbier B, Zorom M, Yacouba H, Dogot T. Farmers perception and willingness to pay for climate information in Burkina Faso. J Agric Sci. 2016;8(1):175-87. https://doi.org/10.5539/jas.v8n1p175.

3. Sultan B. Global warming threatens agricultural productivity in Africa and South Asia. Environ Res Lett. 2012;7: 041001. https://doi.org/10.1088/ 1748-9326/7/4/041001

4. Lodoun T, Giannini A, Traoré PS, et al. Changes in seasonal descriptors of precipitation in Burkina Faso associated with late 20th century drought and recovery in West Africa. Environ Dev. 2013;5(1):96-108. https://doi. org/10.1016/j.envdev.2012.11.010.

5. FAO, IFAD, UNICEF, WFP, WHO. The State of Food Security and Nutrition in the World 2018. Building Climate Resilience for Food Security and Nutrition. Rome, FAO. 2018; Licence: CC BY-NC-SA 3.0 IGO; 2018.

6. FAO, IFAD, UNICEF, WFP, WHO. The State of Food Security and Nutrition in the World 2021. Transforming Food Systems for Food Security, Improved Nutrition and Affordable Healthy Diets for All. FO; 2021. https://doi.org/ 10.4060/ca9692en

7. CSAO/OCDE. Crise Alimentaire et Nutritionnelle 2020, Analyses \& Réponses. Maps \& Facts, No 3; 2020

8. Comité Permanent Inter-Etats de Lutte contre la Sécheresse dans le Sahe (CILSS). Normes de Consommation Des Principaux Produits Alimentaires Dans Les Pays Du Cilss. 2004.

9. Fraval S, Yameogo V, Ayantunde A, et al. Food security in rural Burkina Faso : the importance of consumption of own - farm sourced food versus purchased food. Agric Food Secur. 2020. https://doi.org/10.1186/ s40066-020-0255-z

10. FAO. Strengthening Resilience to Food and Nutrition Insecurity in the Sahel and Western Africa. 2014. http://pscentre.org/wp-content/uploads/ 2018/02/Strengthening-Resilience.pdf

11. FAO. Cereal Supply and Demand Balances for Sub-Saharan African Countries - Situation as of February 2021. https://doi.org/10.4060/cb3674en

12. Biazin B, Sterk G, Temesgen M, Abdulkedir A, Stroosnijder L. Rainwater harvesting and management in rainfed agricultural systems in subSaharan Africa - A review. Phys Chem Earth. 2012;47-48:139-51. https:// doi.org/10.1016/j.pce.2011.08.015.

13. Sanfo S, Barbier B, Dabiré IWP, et al. Rainfall variability adaptation strategies: An ex-ante assessment of supplemental irrigation from farm ponds in southern Burkina Faso. Agric Syst. 2017;152:80-9. https://doi.org/10 1016/j.agsy.2016.12.011

14. Dugue P. L'utilisation Des Ressources En Eau à I 'Échelle d 'Un Village : Perspectives de Développement de Petits Périmètres Irrigués de Saison Des Pluies et de Saison Sèche Au Yatenga . Contraintes Techniques et Socio-Économiques; 1986

15. Somé L. Diagnostic agropédoclimatique du risque de sécheresse au Burkina Faso. Etude de quelques techniques agronomiques améliorant la résistance pour les cultures de sorgho, de mil et de maïs. 1989;(MONTPELLIER II):281.

16. Fox P, Rockström J. Supplemental irrigation for dry-spell mitigation of rainfed agriculture in the Sahel. Agric Water Manag. 2003;61(1):29-50.

17. FAO. The State of Food and Agriculture 2020. Overcoming Water Challenges in Agriculture. 2020. https://doi.org/10.1057/978-1-137-56671-3_ 22

18. Li X, Waddington SR, Dixon J. The relative importance of drought and other water-related constraints for major food crops in South Asian farming systems. Food Secur. 2011;3:19-33. https://doi.org/10.1007/ s12571-011-0111-x

19. Zongo B, Diarra A, Barbier B, Zorom M, Yacouba H, Dogot T. Farmers' practices and willingness to adopt supplemental irrigation in Burkina Faso. Int J Food Agric Econ. 2015;3(1):101-17.

20. Kemeze $\mathrm{FH}$. Economic valuation of supplemental irrigation via smallscale water harvesting. Water Resour Econ. 2020. https://doi.org/10. 1016/j.wre.2020.100160
21. Sarr B, Atta S, Ly M, et al. Journal of Agricultural Extension and Rural Development Adapting to climate variability and change in smallholder farming communities: A case study from Burkina Faso. Chad and Niger. 2015;7(1):16-27. https://doi.org/10.5897/JAERD2014.0595.

22. Zongo B, Diarra A, Barbier B, et al. Ex ante evaluation of supplemental irrigation in a Sahelian context: Coupling biophysical and economic models. Biotechnol Agron Soc Environ. 2019;23(3):14. https://doi.org/10.25518/ 1780-4507.18056

23. Santeramo FG. Food security composite indices: implications for policy and practice. Dev Pract. 2015;25(4):594-600. https://doi.org/10.1080/ 09614524.2015 .1029439$.

24. Cafiero C, Melgar-qui HR, Ballard TJ, Kepple AW. Validity and reliability of food security measures 2. Anal New York Acad od Sci. 2015;40:1-19. https://doi.org/10.1111/nyas.12594

25. Leroy JL, Ruel M, Frongillo EA, Harris J, Ballard TJ. Measuring the food access dimension of food security : a critical review and mapping of indicators. Food Nutr Bull. 2015;36(2):167-95. https://doi.org/10.1177/03795 72115587274.

26. Ike CU, Jacobs PT, Kelly C. A multidimensional approach to measuring household food security in Taraba State, Nigeria: comparing key indicators. Dev Pract. 2017;27(2):234-46. https://doi.org/10.1080/09614524. 2017.1281225

27. Maxwell D, Coates J, Vaitla B. How Do Different Indicators of Household Food Security Compare? Empirical Evidence from Tigray. Feinstein International Center: Tufts University; 2013.

28. Santeramo FG. On the Composite Indicators for Food Security: Decisions Matter ! On the Composite Indicators for Food Security: Decisions Matter ! Food Rev Int. 2015;31:63-73. https://doi.org/10.1080/87559129.2014 961076.

29. Funk CC, Brown ME. Declining global per capita agricultural production and warming oceans threaten food security. Food Secur. 2009:1:271-89. https://doi.org/10.1007/s12571-009-0026-y.

30. Zidouemba RP, Gerard F. Does Agricultural Productivity Actually Matter for Food Security in a Landlocked Sub-Saharan African Country? The Case of Does Agricultural Productivity Actually Matter for Food Security in a Landlocked Sub-Saharan African Country? The Case of Burkina F. Can J Agric Econ. 2018;66(1):106-42. https://doi.org/10.1111/cjag.12140.

31. Lebailly P, Dogot T, Bien VP, Khai TT. La Filière Rizicole Au Sud Du Viêt-Nam. Un Modèle Méthodologique. (Direction génarle de la coopération internale (Belgique), ed.). Les presses agronomiques de Gembloux; 2000.

32. Toutain B, Lhoste P. Essai d'estimation du coefficient d'utilisation de la biomasse herbacée par le bétail dans un périmètre sahélien. Rev Elev vétPays trop. 1978;31(1):95-101.

33. de Valero J, Martın-Benito JMT, Mata EL. MOPECO : an economic optimization model for irrigation water management. Irrig Sci. 2004;23:61-75. https://doi.org/10.1007/s00271-004-0094-x.

34. Li X, Gong J. Effects of different ridge : furrow ratios and supplemental irrigation on crop production in ridge and furrow rainfall harvesting system with mulches. Agric Water M. 2002;54:243-54.

35. Kafle K, Omotilewa O, Leh M, Schmitter P. Who is Likely to Benefit from Public and Private Sector Investments in Farmer-led Irrigation Development ? Evidence from Ethiopia Who is Likely to Benefit from Public and Private Sector Investments in Farmer-led Irrigation Development ? Evidence from Ethi. J Dev Stud. 2021;00(00):1-21. https://doi.org/10.1080/ 00220388.2021 .1939866

36. Merabeta BA, Boutiba A. L'irrigation de complement du ble dur influence de la nature du materiel vegetal et de la variabilite climatique interannuelle dans une plaine semi-aride d'algerie. Sci Technol C. 2005;23:72-9.

37. Alaoui EM. Développement de I'agriculture irriguée, dispositif juridique et institutionnel et stratégie de gestion de I'eau au Maroc. In: Bouarfa S, Kuper M, Debbarh A, eds. L'avenir de l'agriculture Irriguée En Méditerranée. Nouveaux Arrangements Institutionnels Pour Une Gestion de La Demande En Eau. CIRAD; 2007.

38. Barron J, Okwach G. Run-off water havesting for dry spell mitigation in maize (Zea mays L): results from on-fram research in semi-arid Kenya. Agric Water Manag. 2005:74:1-21.

39. Muluneh A, Stroosnijder L, Keesstra S. Adapting to climate change for food security in the Rift Valley dry lands of Ethiopia : supplemental irrigation, plant density and sowing date. J Agric Sci. 2017. https://doi.org/10. 1017/S0021859616000897. 
40. He X-F, Cao H, Li F-M. Econometric analysis of the determinants of adoption of rainwater harvesting and supplementary irrigation technology (RHSIT) in the semiarid Loess Plateau of China. Agric Water Manag. 2007;89(3):243-50.

41. FAO, IFAD, UNICEF, WFP, WHO. The State of Food Security and Nutrition in the World 2020. Transforming Food Systems for Affordable Healthy Diets. FAO; 2020. https://doi.org/10.4060/ca9692en

42. Dembélé Y, Somé L, Zomboudré G, Diabri S. Irrigation de complément du riz pluvial sur des sols sableux conditionnés avec de la matière organique au sud-ouest du Burkina Faso. Sécheresse. 1999;10(2):143-9.

43. Some L, Ouattara K. Irrigation de complément pour améliorer la culture du sorgho au Burkina Faso. Agron Africaine. 2009;17(3):201-9.

44. Panigrahi B, Panda SN, Mal BC. Rainwater conservation and recycling by optimal size on-farm reservoir. Resour Conserv Recycl. 2007;50(4):459-74. https://doi.org/10.1016/j.resconrec.2006.08.002.

\section{Publisher's Note}

Springer Nature remains neutral with regard to jurisdictional claims in published maps and institutional affiliations.

- fast, convenient online submission

- thorough peer review by experienced researchers in your field

- rapid publication on acceptance

- support for research data, including large and complex data types

- gold Open Access which fosters wider collaboration and increased citations

- maximum visibility for your research: over $100 \mathrm{M}$ website views per year

At BMC, research is always in progress.

Learn more biomedcentral.com/submissions 